\title{
Design and deployment of autoclave pressure vessels for the portable deep-sea drill rig MeBo (Meeresboden-Bohrgerät)
}

\author{
Thomas Pape $^{1,2}$, Hans-Jürgen Hohnberg ${ }^{2,3}$, David Wunsch ${ }^{3}$, Erik Anders ${ }^{3}$, Tim Freudenthal ${ }^{2}$, \\ Katrin Huhn ${ }^{2}$, and Gerhard Bohrmann ${ }^{1,2}$ \\ ${ }^{1}$ Department of Geosciences at the University of Bremen, Klagenfurter Str. 4, 28359 Bremen, Germany \\ ${ }^{2}$ MARUM - Center for Marine Environmental Sciences at the University of Bremen, Leobener Str. 8, 28359 \\ Bremen, Germany \\ ${ }^{3}$ Corsyde International GmbH \& CO. KG, Reuchlinstr. 10-11, 10553 Berlin, Germany
}

Correspondence to: Thomas Pape (tpape@ marum.de)

Received: 22 January 2017 - Revised: 27 April 2017 - Accepted: 8 May 2017 - Published: 30 November 2017

\begin{abstract}
Pressure barrels for sampling and preservation of submarine sediments under in situ pressure with the robotic sea-floor drill rig MeBo (Meeresboden-Bohrgerät) housed at the MARUM (Bremen, Germany) were developed. Deployments of the so-called "MDP" (MeBo pressure vessel) during two offshore expeditions off New Zealand and off Spitsbergen, Norway, resulted in the recovery of sediment cores with pressure stages equaling in situ hydrostatic pressure. While initially designed for the quantification of gas and gas-hydrate contents in submarine sediments, the MDP also allows for analysis of the sediments under in situ pressure with methods typically applied by researchers from other scientific fields (geotechnics, sedimentology, microbiology, etc.). Here we report on the design and operational procedure of the MDP and demonstrate full functionality by presenting the first results from pressure-core degassing and molecular gas analysis.
\end{abstract}

\section{Introduction}

Pressure coring is currently the only method that enables precise off-site analysis of gas and gas hydrate volumes contained in marine sediments. Because the manufacture of pressure-coring tools and their operational application are technically challenging, pressure vessels have only been in use for the last few decades. A review of pressure-coring systems used for offshore research from various platforms in the past and today is presented elsewhere (Abid et al., 2015 and references cited therein). These include the Dynamic Autoclave Piston Corer (DAPC) which is frequently in use for pressure coring of shallow (down to $2.65 \mathrm{~m}$ below the sea floor, hereafter $\mathrm{m}$ b.s.f.) gas-hydrate-bearing sediments at the MARUM - Center for Marine Environmental Sciences since the early 2000s (e.g., Abegg et al., 2008; Heeschen et al., 2007; Pape et al., 2011a).

In 2005, the sea-floor drill rig MARUM-MeBo70 (acronym for Meeresboden-Bohrgerät, German for sea-floor drill rig), initially designed to obtain non-pressurized sediment cores from a depth of up to $70 \mathrm{~m}$ b.s.f., was operated for the first time (Freudenthal and Wefer, 2007, 2013). MeBo70 is a robotic drill remotely controlled from conventional research vessels via an umbilical cable that allows for sampling of the sea bed by push core or rotary core drilling. Compared to those of drilling vessels, the advantages of seafloor drill rigs are optimal control over the drilling process at the sea floor, great flexibility in use from various vessels, and time and cost efficiency. For lowering sampling tools and measurement devices into the well, the comparably fast wireline drilling technique is used (Freudenthal and Wefer, 2013). In 2014 the second MeBo generation, MARUMMeBo200, which allows core drillings to be conducted down to $200 \mathrm{~m}$ b.s.f. by means of wireline technology, was additionally taken into use. Gas-hydrate-bearing sediments from depths exceeding $10 \mathrm{~m}$ b.s.f. in the eastern Black Sea (unpublished data) and in the Gulf of Guinea (Sultan et al., 2014; Wei et al., 2015) were recovered in 2011 with MeBo70 for 

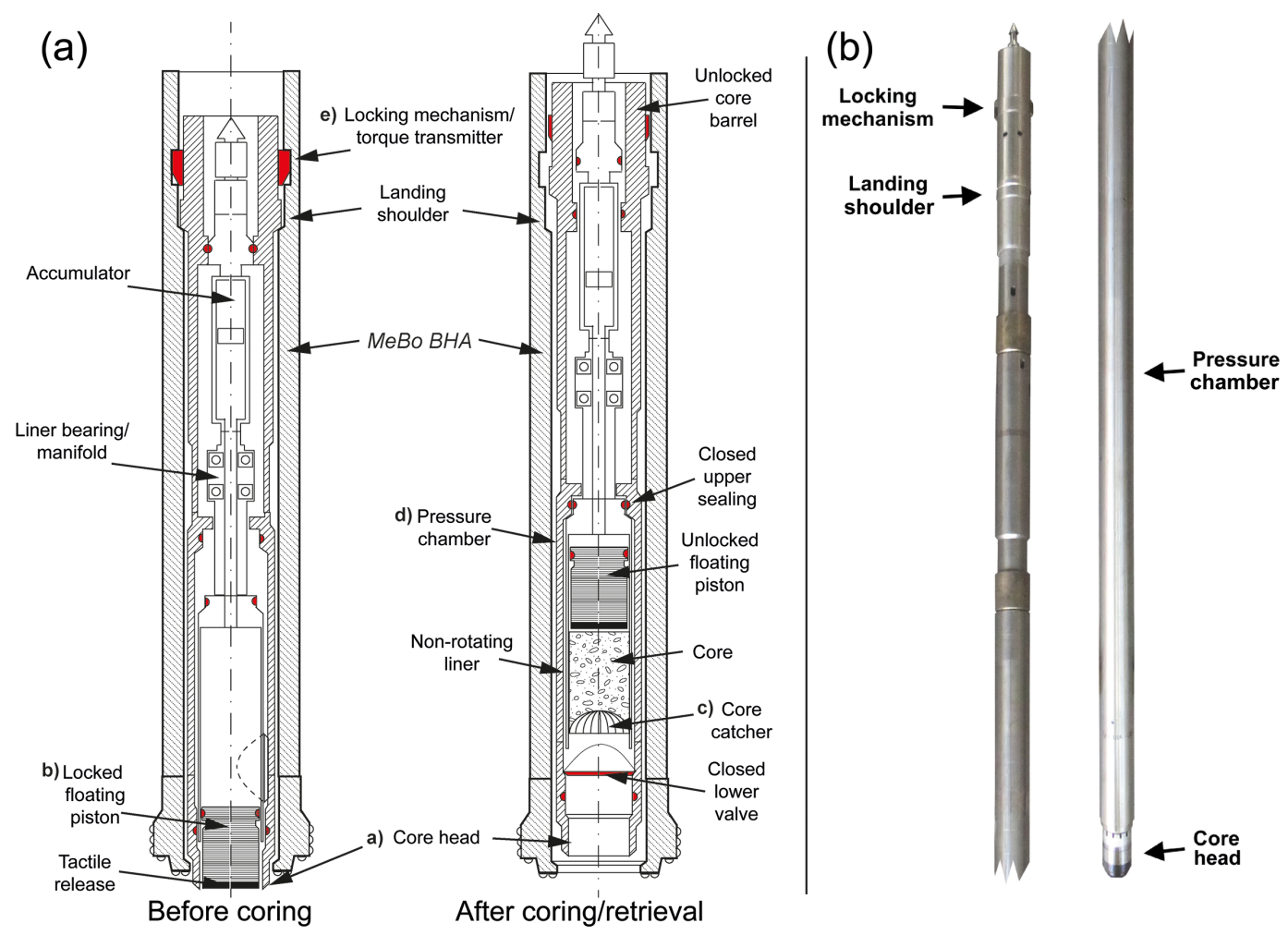

Figure 1. (a) Scheme and working principle of the MeBo pressure vessel (MDP; not in scale). BHA = bottom hole assembly. (b) Photograph of the MDP (left: top part; right: bottom part).

qualitative analysis. However, during both sampling campaigns, sediments below the maximum penetration depth of the DAPC eluded analysis of accurate gas volumes since appropriate techniques were unavailable.

Recently, a pressure-core barrel has been developed within the German collaborative project "SUGAR" for use with both systems, MeBo70 and MeBo200. The pressurecore barrel, called MDP (German for MeBo-DruckkernProbennehmer), is employed like a wireline inner core barrel. Pressure coring with the MDP was successfully carried out during two subsequent deep-sea cruises with MeBo200 (east of New Zealand) and MeBo70 (west of Spitsbergen) in 2016. Hence, a system is now available that allows for the recovery of pressurized sediment cores with both MeBo systems and for subsequent quantitative sampling of gas from these. Here we report on the design and deployment of the MDP and demonstrate their complete functionality by presenting first results from pressure coring and pressure-core processing.

\section{Design and deployment}

\subsection{Design, specifications, and operational procedure}

The MDP principally consists of (a) a cutting shoe or core head cutting the sediment core with the required core diameter, (b) a floating piston using hydrostatic pressure to force the penetration of the sediment core into the core barrel, (c) a core catcher that inhibits loss of sediment before the valve is closed, (d) a pressure housing and a valve that closes after the coring process in order to keep the in situ pressure within the core barrel, and (e) a latching device that ensures the correct position of the pressure-core barrel within the MeBo drill string and that activates the closing of the valve when the core barrel is pulled with an "overshot" using the wireline technique (Fig. 1). Titanium was used to manufacture all pressure-holding parts, which facilitates future imaging of pressurized sediment cores by computerized tomography.

As a consequence of required implementations of several activation and lifting mechanisms, the MDP core barrel has a shorter length and a smaller diameter compared to conventional MeBo core barrels (Table 1), resulting in a smaller liner volume. In order to support sediment intrusion into the liner, a piston system has been developed which allows the cutting of a core that has a relatively small diameter compared to the borehole diameter. This system is based on using the physical principle of the increasing hydrostatic pressure when lowering the MeBo from the vessel to the sea floor. A sealed atmosphere within the MDP generates a differential pressure, which at the time of coring drives the piston upwards with the relative downward movement of the drill string. Usage of the differential pressure to support sediment intrusion while coring soft sediments is a unique method 
Table 1. Specifications of the conventional core barrels and the MDP operated with MeBo70 or MeBo200.

\begin{tabular}{llrr}
\hline Specification & & $\begin{array}{r}\text { Conventional barrel - } \\
\text { MeBo70/MeBo200 }\end{array}$ & $\begin{array}{r}\text { MDP - } \\
\text { MeBo70/MeBo200 }\end{array}$ \\
\hline Barrel outer diameter & $(\mathrm{mm})$ & $73 / 73$ & $73 / 73$ \\
Barrel length, approx. & $(\mathrm{mm})$ & $3400 / 4300$ & $3400 / 4300$ \\
Core diameter & $(\mathrm{mm})$ & $55 / 55$ & $45 / 45$ \\
Maximum core length & $(\mathrm{mm})$ & $2500 / 3500$ & $1300 / 1300$ \\
Maximum core volume & $(\mathrm{L})$ & $5.94 / 8.32$ & $2.07 / 2.07$ \\
Operating pressure & $(\mathrm{MPa})$ & $\mathrm{n} / \mathrm{a} / \mathrm{n} / \mathrm{a}$ & $20 / 20$ \\
\hline
\end{tabular}

$\mathrm{n} / \mathrm{a}=$ not applicable

(Hohnberg, 2010, patent pending). The piston is locked mechanically before operation and released when a touch sensor strikes the sediment at the drill-hole bottom at the beginning of the coring process. During coring the piston is driven upwards by the hydrostatic pressure at the depth of the borehole. This procedure allows the application of a drilling speed that is higher than that of conventional corers and supports receipt of high-quality cores with comparably high recovery rates (see Sect. 3.2). It adopts the advantages of piston coring but minimizes the adverse impact on the recoverable core-length-to-tool-length ratio. A damping system positioned above the piston regulates the raising velocity of both the piston and the incoming sediment core. After the core has been cut, the overshot is lowered into the drill string in the same way as in the recovery procedure of conventional MeBo core barrels. Once the overshot is latched onto the MDP locking mechanism, the wireline is pulled. Before unlocking the MDP the sealing mechanisms are released by an additional axial lift in the upper part of the tool. Closing of valves at the top and the bottom section of the pressure chamber assures pressure-tight recovery of the core under near in situ pressure. Furthermore, a special pre-configured accumulator is activated in order to compensate for potential changes in pressure due to temperature fluctuations throughout the recovery process and to ensure pressure tightness of the system, thus preserving near in situ pressure during recovery and storage. During pre-configuration the internal pressure of the accumulator is adjusted to as close to the hydrostatic downhole pressure as possible. A significant higher initial pressure ("overcharge") should be avoided since it lasts on the core and may lead to sample alteration and misinterpretations of core properties.

\subsection{Deployments and operations with MeBo200 and MeBo70}

The MDPs were successfully deployed, with both MeBo200 and MeBo70, during two campaigns in deep-sea areas in 2016. Cruise SO247 with the German RV Sonne in spring 2016 off New Zealand (Huhn, 2016) provided excellent opportunities for trial-and-error tests and to adjust the MDP for pressure coring with MeBo200 within sediments consid- ered to partially host gas hydrates (see Table A1 in the Appendix for core specifications). During that cruise the capability to achieve excellent core recovery rates as well as pressure cores with the MDPs was proven (see Sect. 3). MDP coring was additionally performed during cruise MSM57/1 with RV Maria S. Merian in summer 2016 off Spitsbergen (Bohrmann et al., 2017). Before deployment parts of the MDPs were modified after consideration of the test results of drillings conducted during $\mathrm{SO} 247$ and of technical requirements for usage with MeBo70. During MSM57/1, MDPs were used three times at two sites (Table A1 in the Appendix). While MeBo station GeoB21613-1 was carried out at a reference site expected to be virtually devoid of gas hydrates, GeoB21616-2 was performed within an active pockmark and assumed to contain gas hydrates.

\subsection{Handling of MDP core barrel after recovery and core processing}

After the MeBo has been recovered and the MDPs were removed from the magazine, mechanical components above and below the pressure chamber were dissembled in order to make the MDP's pressure-bearing parts accessible. An assembly of gas-tight valves and ports (modified after Dickens et al., 2003; Heeschen et al., 2007; and Shipboard Scientific Party, 1996) and a pressure sensor for continuous monitoring of the internal pressure were connected to the MDP pressure chamber. During cruise MSM57/1, pressurized fluid (gas and water) was released incrementally from the pressure chamber into a gas-tight, scaled syringe for gas sub-sampling and determinations of fluid volumes. Quantification of released fluids was carried out on-deck at atmospheric pressure and ambient temperature (ca. 2 to $6^{\circ} \mathrm{C}$ ).

Repeatedly, after release of a certain gas volume, gas subsamples were taken and transferred into glass serum vials for analysis of molecular compositions $\left(\mathrm{C}_{1}-\mathrm{C}_{6}\right.$ hydrocarbons, $\mathrm{N}_{2}, \mathrm{O}_{2}$, Ar; Pape et al., 2010a). Subsequent to degassing (when pressure inside the pressure chamber has dropped to atmospheric pressure), the core liner containing the depressurized sediment core was removed from the pressure chamber through the lower valve. Since the technical principle of the MDP does not comprise a transparent core liner for 
subsequent core description, the sediment core needed to be transferred into a suitable liner. A piston system was used to push the core into a liner in a sliding motion. Finally, the core was processed like a conventional core (e.g., through splitting, lithological description, photography, and storage).

\section{Results and discussion}

The main objectives of the MDP deployments during SO247 were to identify best practice and settings for MDP pressure coring, to technically meet the requirements of both MeBo systems (MeBo70 and MeBo200), and to fit for accomplishing the main goals of cruise MSM57/1. The major objectives of that cruise were to recover cores under pressure and to subsequently carry out a controlled pressure reduction. This degassing procedure would allow for a quantitative determination of the gas in situ amount, which is largely lost when a core is recovered by conventional means.

\subsection{Proof of functionality - deep-water deployments}

MDPs have been deployed with MeBo200 during SO247 nine times and with MeBo70 three times during MSM57/1 (Fig. 2, Table A1 in Appendix). During SO247, recovery rates with the MDP of more than $82 \%$ where obtained during five deployments, of which two exceeded $97 \%$. Virtually no sediments were recovered during two deployments only.

Two pressurized samples (GeoB20802-6 (2P): sediment core (99\% recovery rate) and GeoB20846-1 (13P): fluid sample from overconsolidated silt section) were received during SO247, both with pressure higher than in situ values (Fig. 2). Although quantitative degassing of the pressure core GeoB20802-6 (2P) could not be executed properly due to technical issues, the two main technical aspects of the MDP (piston coring, preservation of in situ pressure) have been proven to work during $\mathrm{SO} 247$. It should be pointed out that the deepest sediments at stations GeoB20803-2, 208244, 20831-3, and 20846-1 were collected with the MDP.

During and after cruise $\mathrm{SO} 247$, an intense evaluation of the MDP system with regard to core recovery and operation was carried out. Modifications on the sealing concept, the lifting and unlocking mechanisms, and the downstream degassing procedures as well as minor changes of the floating piston led to improvements in handling and operation of the pressure-core barrel and in core analysis. The improvements resulted in an increase of the core barrel's overall reliability and performance, which has been proven throughout MSM57/1 (Fig. 2). Standardized procedures and comprehensive documentation enabled repeated deployment of the MDP on a routine basis. This will facilitate to establish the MDP deployments as a "near conventional" operation in MeBo coring.

During MSM57/1, MDPs have been deployed three times with MeBo70 (Table A1, Appendix). During all operations pressurized samples (two sediment cores and one fluid sam-

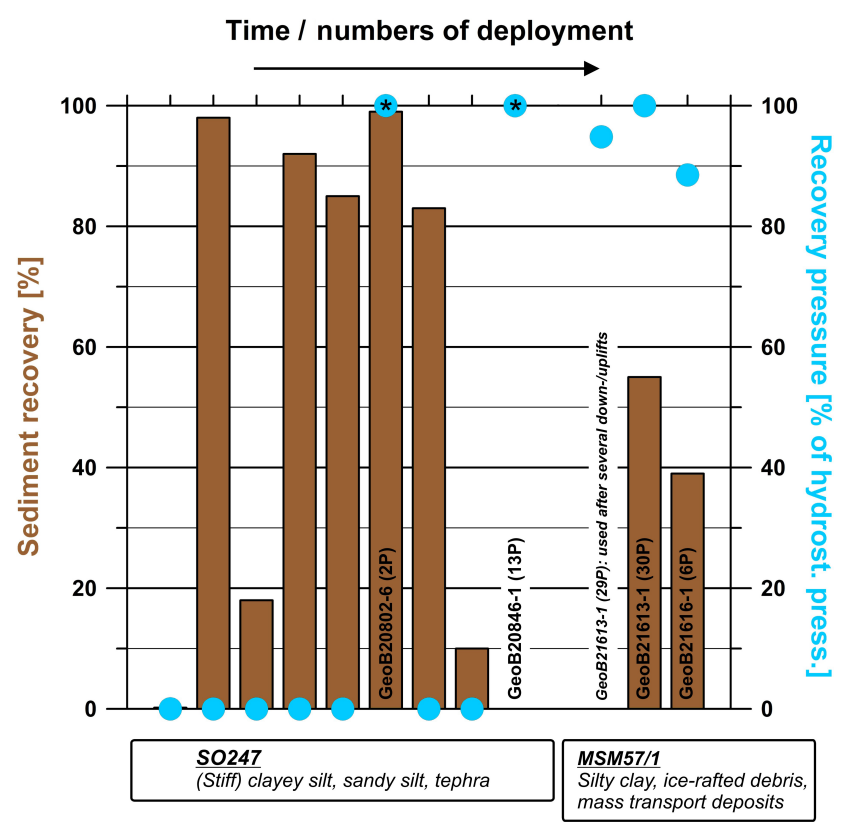

Figure 2. Overview of sediment recovery rates (in percentage of liner volume) and recovery pressure (in percentage of hydrostatic pressure at the drill site) obtained in the course of MDP deployments and modifications during cruises SO247 and MSM57/1. * = Pressure inside pressure vessel higher than hydrostatic pressure due to initial overcharge by the pressure accumulator. Specifications of drill sites are provided in Table A1 in the Appendix.

ple) were recovered. The average sediment recovery of the two pressurized sediment cores was $47.0 \%$. The deepest sediments at stations GeoB21613-1 and 21616-1 were collected with MDPs (sections 30P and 6P, respectively). The lack of sediment in barrel GeoB21613-1 (29P), which was initially prepared for operation during preceding stations, most likely resulted from a technical malfunction of the piston system. This was probably caused by periodically changing pressure regimes over the course of four lowerings and three liftings of MeBo before final deployment of the MDP.

\subsection{Core recoveries}

Except for single MDPs at three sites (GeoB20803-2 (3P), 20802-6 (3P), and 21613-1 (29P)) and both MDPs recovered from site GeoB20846-1, core recoveries with the MDP exceeded average recoveries calculated for all barrels (conventional core barrels plus MDP) retrieved from that site (Fig. 3).

These results suggest that the floating piston system of the MDP supports the core intrusion process and, thus, leads to a relatively higher core recovery. However, since different sediment properties and drilling parameters might have affected core recoveries, further investigations are required to evaluate the overall functionality of the MDP piston system. 
Table 2. Degassing characteristics of pressure cores (total fluid volume $=$ total water volume + total gas volume)

\begin{tabular}{lrrrrrrr}
\hline GeoB & $\begin{array}{r}\text { Section } \\
\text { no. }\end{array}$ & $\begin{array}{r}\text { Core } \\
\text { length } \\
\mathrm{mm}\end{array}$ & $\begin{array}{r}\text { Core } \\
\text { volume } \\
\mathrm{L}\end{array}$ & $\begin{array}{r}\text { Total water } \\
\text { volume released } \\
\mathrm{L}\end{array}$ & $\begin{array}{r}\text { Total gas } \\
\text { volume released } \\
\mathrm{L}\end{array}$ & $\begin{array}{r}\text { Total fluid } \\
\text { volume released } \\
\mathrm{L}\end{array}$ & $\begin{array}{r}\text { Volumetric fluid }- \\
\text { sediment ratio } \\
\mathrm{LL}^{-1}\end{array}$ \\
\hline MSM57/1 & & & & & & & \\
\hline $21613-1$ & $30 \mathrm{P}$ & 550 & 0.8747 & 0.646 & 0.511 & 1.157 & 1.323 \\
$21616-1$ & 6P & 390 & 0.6203 & 0.249 & 0.351 & 0.600 & 0.967 \\
\hline
\end{tabular}

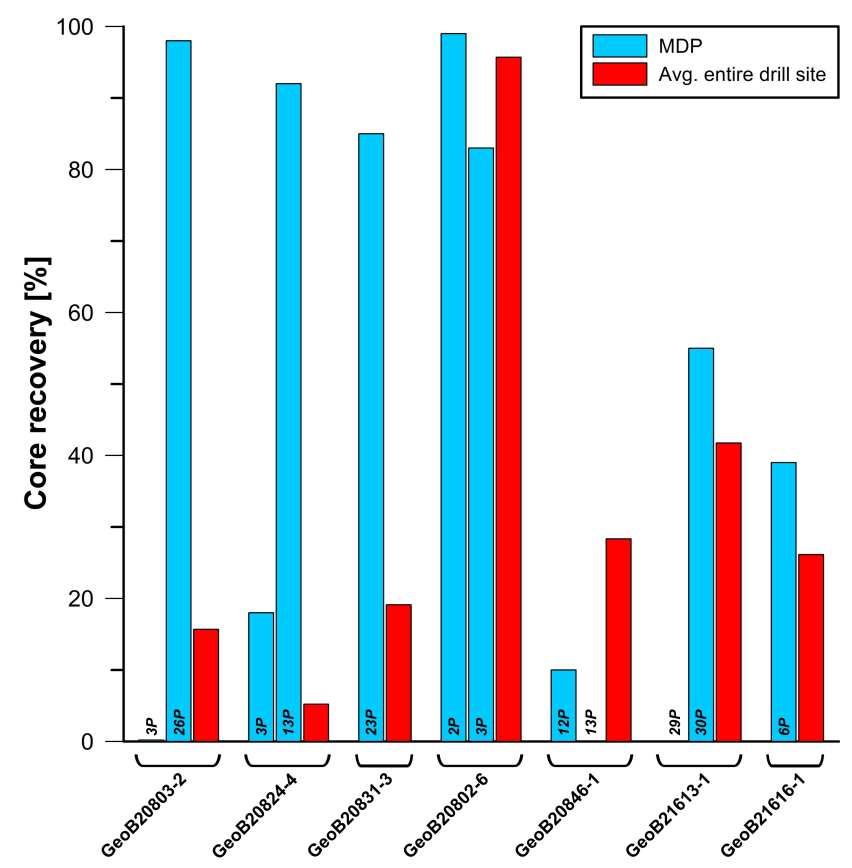

Figure 3. Comparative overview of average core recovery rates at individual drill sites (considering conventional core barrels and MDP, in red) and recovery rates of single MDPs at same drill sites (in blue).

\subsection{Degassing of MDP cores}

Both pressure cores obtained during MSM57/1 were degassed quantitatively while the evolution of pressure inside the MDP pressure chamber was recorded (Fig. 4). Degassing characteristics of these cores are given in Table 2.

For both pressure cores degassed during MSM57/1, a slight saw-tooth-like shape of the pressure-time profile was observed at the initial stage of incremental gas removal (time span ca. 5-40 min). This pattern has been attributed to the presence of gas hydrates in earlier studies (e.g., Dickens et al., 2000, 2003). However, fluid-to-sediment ratios of ca. 1.3 and $1.0 \mathrm{LL}^{-1}$ (Table 2), are low compared to those in gas-hydrate-bearing sediment cores (e.g., Pape et al., 2010b, 2011a, b) and do not support the presence of hydrates in these cores. Instead, temporal small-scale pressure increases dur- ing core degassing may be attributed to sudden formation of migration pathways.

Analysis of molecular composition demonstrated that gas released from 30P nearly exclusively consisted of light hydrocarbons, which predominantly originate from thermocatalysis of organic matter in the deep subsurface $\left(C_{1} /\left(C_{2}+C_{3}\right)=253\right.$; Whiticar, 1999, Table 3$)$. In contrast, nitrogen, oxygen, and argon were found in relatively high portions in the gas released from core GeoB21616-1 (6P). The presence of these components in the released gas was most likely due to atmospheric air that is generally required for the functionality of the MDP piston system and might be partially trapped inside the pressure chamber. Air is meant to be quantitatively released prior to the sealing of the pressure vessel, but residual amounts may still remain inside. Nevertheless, molecular compositions clearly showed that microbial hydrocarbons $\left(\mathrm{C}_{1} /\left(\mathrm{C}_{2}+\mathrm{C}_{3}\right)=1000\right)$ were prevailing at that depth. Void gas samples prepared from shallower sediments recovered with conventional MeBo barrels at both sites showed very similar molecular hydrocarbon compositions (data not shown), thus demonstrating the high quality of the gas obtained with the MDP. Preliminary calculations considering fluid volumes released during degassing, methane percentage in the fluid, and assumed sediment pore volume in the core suggest that the released methane exclusively resulted from exsolution caused by pressure reduction.

The results obtained during MSM57/1 substantiate that pressure vessels with full functionality are now available for the sea-floor drill rigs MeBo70 and MeBo200.

\section{Conclusions and perspectives}

Pressure vessels that enable sampling of deep-sea sediments under hydrostatic pressure with the sea-floor drill rigs MeBo70 and MeBo200 were successfully deployed during two cruises in 2016. Core recovery rates usually exceeded those of the conventional corers and core preservation under pressure was achieved for three cores. Successful quantitative degassing and the quality of light hydrocarbons originating from processes in the subsurface clearly demonstrate that the MeBo pressure vessels are now suitable for routine operations.

The MDPs were mainly designed for the recovery and preservation of gas-hydrate-bearing sediments and also for 

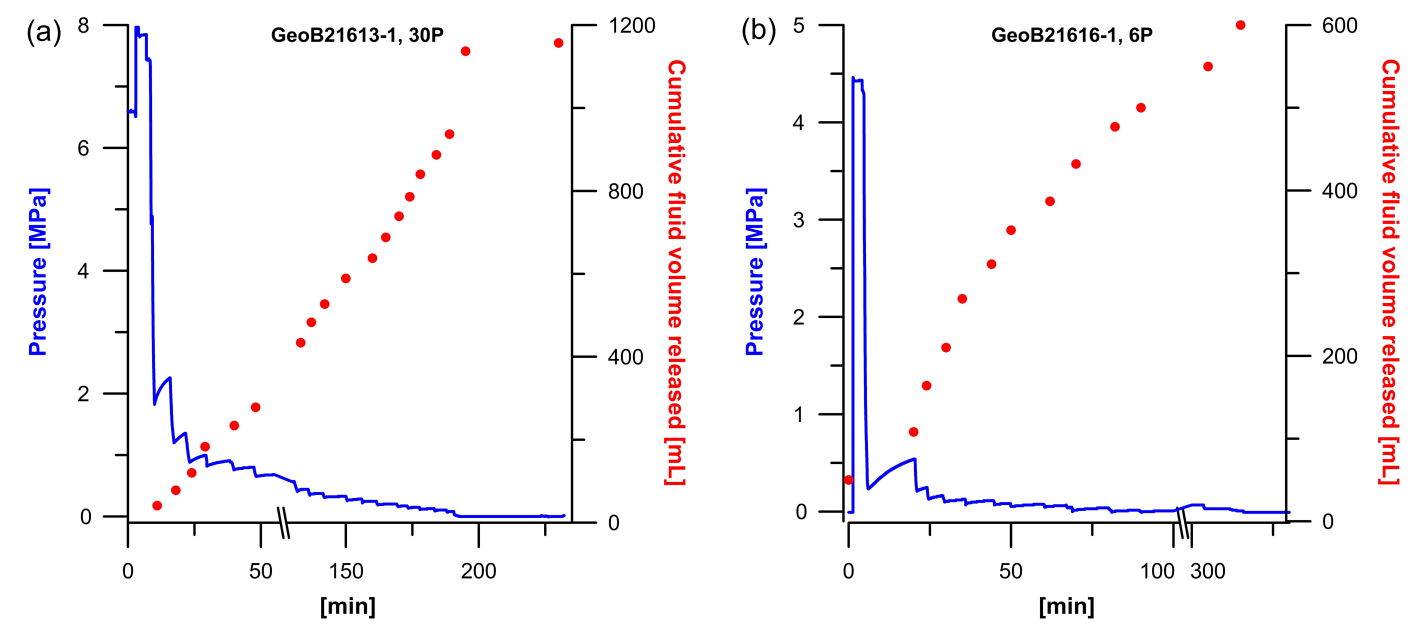

Figure 4. Degassing characteristics of two pressurized sediment cores collected with MeBo70 during cruise MSM57/1. (a) Pressure and cumulative fluid volume released vs. time during degassing of section GeoB21613-1 (30P). (b) Pressure and cumulative fluid volume released vs. time during degassing of section GeoB21616-1 (6P).

Table 3. Average molecular composition of gas released from pressure cores during MSM57/1 (100 mol \% = all volatiles stated).

\begin{tabular}{lrrrrrrr}
\hline GeoB & Section no. & $\mathrm{CH}_{4}$ & $\mathrm{C}_{2} \mathrm{H}_{6}$ & $\mathrm{C}_{3} \mathrm{H}_{8}$ & $\mathrm{C}_{1} /\left(\mathrm{C}_{2}+\mathrm{C}_{3}\right)$ & $\mathrm{N}_{2}$ & $\mathrm{O}_{2}+\mathrm{Ar}$ \\
\hline $21613-1$ & $30 \mathrm{P}$ & 79.88 & 0.31 & 0.01 & 253.0 & 16.58 & 3.23 \\
$21616-1$ & $6 \mathrm{P}$ & 43.92 & 0.04 & b.d.1. & 1000.0 & 46.59 & 9.45 \\
\hline
\end{tabular}

b.d.l. = below detection limit $(<0.005 \mathrm{~mol} \%)$

the precise determination of true gas amounts. However, comparably low volumetric gas-sediment ratios obtained from pressurized cores so far show that the MDPs are not only applicable for the retrieval of gas and gas-hydrate-rich sediments but are also appropriate for collecting sediments hosting relatively small gas amounts.

Relevant components of the MDP were manufactured from titanium, which allows for the scanning of undisturbed pressure cores with non-destructive techniques (e.g., with Xrays, gamma rays, sonic waves) during future operations, as has already been done on cores retrieved with other pressurecoring tools (e.g., Riedel et al., 2006; Suzuki et al., 2015). In addition, a MDP subsampling and transfer system will enable segmentation of pressure cores and storage of core segments in smaller pressure cells for the analysis in spatially high resolution and further processing methods in the future. 


\section{Appendix A}

Table A1. Overview of sections cored with MDP during SO247 (MeBo200) and MSM57/1 (MeBo70) (in chronological order). Further information on cores collected during the cruises are provided in the cruise reports (Huhn, 2016; Bohrmann et al., 2017).

\begin{tabular}{|c|c|c|c|c|c|c|c|c|}
\hline $\begin{array}{l}\text { Station } \\
\text { GeoB (section no.) }\end{array}$ & $\begin{array}{l}\text { Latitude } \\
\qquad\left({ }^{\circ} \mathrm{S}\right)\end{array}$ & $\begin{array}{l}\text { Longitude } \\
\qquad\left({ }^{\circ} \mathrm{E}\right)\end{array}$ & $\begin{array}{r}\text { Water } \\
\text { depth } \\
(\mathrm{m})\end{array}$ & $\begin{array}{r}\text { Core top } \\
\text { depth } \\
\text { (m b.s.f.) }\end{array}$ & $\begin{array}{r}\text { Core bottom } \\
\text { depth } \\
(\mathrm{m} \text { b.s.f. })\end{array}$ & $\begin{array}{r}\text { Sediment } \\
\text { recovery } \\
(\%)\end{array}$ & $\begin{array}{r}\text { Recovery } \\
\text { pressure } \\
(\mathrm{MPa})\end{array}$ & Remarks \\
\hline $20803-2(3 \mathrm{P})$ & $38^{\circ} 49.19^{\prime} \mathrm{S}$ & $178^{\circ} 27.86^{\prime} \mathrm{E}$ & 670 & 7.40 & 8.70 & 0.2 & 0.00 & clayey silt \\
\hline 20803-2 (26P) & $38^{\circ} 49.19^{\prime} \mathrm{S}$ & $178^{\circ} 27.86^{\prime} \mathrm{E}$ & 670 & 80.90 & 82.20 & 98.0 & 0.00 & clay-rich silt \\
\hline $20824-4(3 P)$ & $40^{\circ} 2.04^{\prime} \mathrm{S}$ & $178^{\circ} 9.71^{\prime} \mathrm{E}$ & 670 & 7.40 & 8.70 & 18.0 & 0.00 & overconsolidated silt \\
\hline 20824-4 (13P) & $40^{\circ} 2.04^{\prime} \mathrm{S}$ & $178^{\circ} 9.71^{\prime} \mathrm{E}$ & 670 & 35.40 & 36.70 & 92.0 & 0.00 & overconsolidated silt \\
\hline $20831-3(23 \mathrm{P})$ & $38^{\circ} 49.77^{\prime} \mathrm{S}$ & $178^{\circ} 28.56^{\prime} \mathrm{E}$ & 718 & 77.40 & 78.70 & 85.0 & 0.00 & clayey silt \\
\hline $20802-6(2 \mathrm{P})$ & $38^{\circ} 45.93^{\prime} \mathrm{S}$ & $178^{\circ} 29.01^{\prime} \mathrm{E}$ & 546 & 23.15 & 24.20 & 99.0 & $11.9^{*}$ & clayey silt \\
\hline $20802-6(3 \mathrm{P})$ & $38^{\circ} 45.93^{\prime} \mathrm{S}$ & $178^{\circ} 29.01^{\prime} \mathrm{E}$ & 546 & 24.20 & 24.90 & 83.0 & 0.00 & clayey silt \\
\hline $20846-1(12 P)$ & $40^{\circ} 01.50^{\prime} \mathrm{S}$ & $178^{\circ} 10.70^{\prime} \mathrm{E}$ & 550 & 38.90 & 40.00 & 10.0 & 0.00 & $\begin{array}{r}\text { overconsolidated silt } \\
\text { and tephra }\end{array}$ \\
\hline \multirow[t]{2}{*}{$20846-1(13 P)$} & $40^{\circ} 01.50^{\prime} \mathrm{S}$ & $178^{\circ} 10.70^{\prime} \mathrm{E}$ & 550 & 40.00 & 41.00 & 0.0 & $9.93^{*}$ & $\begin{array}{r}\text { overconsolidated silt } \\
\text { and tephra }\end{array}$ \\
\hline & & & & & average & 53.9 & & \\
\hline $21613-1$ (29P) & $78^{\circ} 59.81^{\prime} \mathrm{N}$ & $6^{\circ} 57.81^{\prime} \mathrm{E}$ & 1200 & 60.30 & 61.40 & 0.0 & 11.38 & $\begin{array}{r}\text { Deployed after several } \\
\text { down- and uplifts of the tool }\end{array}$ \\
\hline 21613-1 (30P) & $78^{\circ} 59.81^{\prime} \mathrm{N}$ & $6^{\circ} 57.81^{\prime} \mathrm{E}$ & 1200 & 61.40 & 62.50 & 55.0 & 12.00 & silty clay \\
\hline \multirow[t]{2}{*}{$21616-1(6 \mathrm{P})$} & $79^{\circ} 00.42^{\prime} \mathrm{N}$ & $6^{\circ} 54.25^{\prime} \mathrm{E}$ & 1210 & 12.80 & 13.90 & 39.0 & 10.71 & clay \\
\hline & & & & & average & 31.3 & & \\
\hline
\end{tabular}

* Pressure inside pressure vessel higher than hydrostatic pressure due to an initial overcharge by the activated accumulator. 
Data availability. All data reported are made publicly available through the PANGAEA information system (Data Publisher for Earth and Environmental Science) sustained by the World Data Center for Marine Environmental Sciences (WDCMARE). Data from research cruises SO247 and MSM57/1 are publicly accessible through the PANGAEA information system via https://www.pangaea.de/expeditions/cr.php/Merian and https:// www.pangaea.de/expeditions/cr.php/Sonne_2014.

Author contributions. TP conducted degassing experiments with the MDP during cruises SO247 and MSM57/1. HJH designed, built, and modified MDP, tested them in the lab and during cruises with MeBo in 2011, prepared MDP for deployment during SO247, and proposed drill parameters. DW prepared MDP for deployment during SO247 and MSM57/1 and proposed drill parameters. EA participated in lab tests of MDP and designed technical modifications. TF supervised drilling procedures with MDP and MeBo and proposed drill parameters. KH led cruise $\mathrm{SO} 247$ and proposed MDP deployment depths. GB proposed development of pressure vessels for the deep-sea drill rig MeBo within the German gas-hydraterelated project SUGAR, led cruise MSM57/1, and proposed MDP deployment depths. TP prepared the paper with contributions from all co-authors.

Competing interests. The authors declare that they have no conflict of interest.

Acknowledgements. Masters and crews of SO247 and MSM57/1 as well as the MeBo teams are greatly acknowledged for their excellent support during the field campaigns. We are very grateful to the co-chief scientist of SO247, N. Kukowski, Friedrich Schiller University Jena, Germany, for providing opportunities to deploy the MeBo pressure vessels (MDPs). The authors wish to thank Andrew Wright (Geoquip Marine Operations AG), Koji Yamamoto (Technology and Research Center, Japan Oil, Gas and Metals National Corporation; JOGMEC), and the handling editor of the journal, Thomas Wiersberg, for their constructive comments on this manuscript. Design and development of the MDPs were funded by the German Federal Ministry for Economic Affairs and Energy through the collaborative project SUGAR (Submarine Gashydrate Resources; 03SX250B).

Edited by: T. Wiersberg

Reviewed by: K. Yamamoto and A. Wright

\section{References}

Abegg, F., Hohnberg, H.-J., Pape, T., Bohrmann, G., and Freitag, J.: Development and application of pressure-coresampling systems for the investigation of gas- and gas-hydratebearing sediments, Deep-Sea Res. Pt. I., 55, 1590-1599, https://doi.org/10.1016/j.dsr.2008.06.006, 2008.

Abid, K., Spagnoli, G., Teodoriu, C., and Falcone, G.: Review of pressure coring systems for offshore gas hydrates research, Un- derwater Technol., 33, 19-30, https://doi.org/10.3723/ut.33.019, 2015.

Bohrmann, G. and cruise participants: R/V MARIA S. MERIAN Cruise Report MSM57, Gas Hydrate Dynamics at the Continental Margin of Svalbard, Reykjavik - Longyearbyen - Reykjavik, 29 July-7 September 2016, 204 pp., available at: http: //elib.suub.uni-bremen.de/edocs/00105895-1.pdf, 2017.

Dickens, G. R., Wallace, P. J., Paull, C. K., and Borowski, W. S.: Detection of methane gas hydrate in the pressure core sampler (PCS): Volume-pressure-time relations during controlled degassing experiments, in: Proc. ODP, Sci. Res., edited by: Paull, C. K., Matsumoto, R., Wallace, P. J., and Dillon, W. P., College Station, TX (Ocean Drilling Program), 113-126, https://doi.org/10.2973/odp.proc.sr.164.210.2000, 2000.

Dickens, G. R., Schroeder, D., Hinrichs, K.-U., and the Leg 201 Scientific Party: The pressure core sampler (PCS) on ODP Leg 201: General operations and gas release, in: Proc. ODP, Init. Repts., edited by: D’Hondt, S. L., Jørgensen, B. B., Miller, D. J., et al., 201: College Station, TX (Ocean Drilling Program), 1-22, https://doi.org/10.2973/odp.proc.ir.201.103.2003, 2003.

Freudenthal, T. and Wefer, G.: Scientific Drilling with the Sea Floor Drill Rig MeBo, Sci. Dril., 5, 63-66, https://doi.org/10.2204/iodp.sd.5.11.2007, 2007.

Freudenthal, T. and Wefer, G.: Drilling cores on the sea floor with the remote-controlled sea floor drilling rig MeBo, Geosci. Instrum. Method. Data Syst., 2, 329-337, https://doi.org/10.5194/gi-2-329-2013, 2013.

Heeschen, K. U., Hohnberg, H. J., Haeckel, M., Abegg, F., Drews, M., and Bohrmann, G.: In situ hydrocarbon concentrations from pressurized cores in surface sediments, Northern Gulf of Mexico, Mar. Chem., 107, 498-515, https://doi.org/10.1016/j.marchem.2007.08.008, 2007.

Hohnberg, H.-J.: Kernbohrtechnische Vorrichtung für die Unterstützung der Beprobung von Sedimenten mit Kernbohrgeräten am Bohrlochgrund von Bohrungen bei überdeckenden statischen Flüssigkeitsdrücken, wie z.B. in der Tiefsee, German Patent and Trade Mark Office (DPMA), Application number 102008049795 A1, 2010.

Huhn, K.: Cruise Report / Fahrtbericht SO247 - SlamZ: Slide activity on the Hikurangi margin, New Zealand, Wellington (NZ): 27 March 2016 - Auckland (NZ): 27 April 2016, MARUM, Center for Marine Environmental Sciences, University of Bremen, 119 pp., https://doi.org/10.2312/cr_so247, 2016.

Pape, T., Bahr, A., Rethemeyer, J., Kessler, J. D., Sahling, H., Hinrichs, K.-U., Klapp, S. A., Reeburgh, W. S., and Bohrmann, G.: Molecular and isotopic partitioning of low-molecular weight hydrocarbons during migration and gas hydrate precipitation in deposits of a high-flux seepage site, Chem. Geol., 269, 350-363, https://doi.org/10.1016/j.chemgeo.2009.10.009, 2010a.

Pape, T., Kasten, S., Zabel, M., Bahr, A., Abegg, F., Hohnberg, H.-J., and Bohrmann, G.: Gas hydrates in shallow deposits of the Amsterdam mud volcano, Anaximander Mountains, Northeastern Mediterranean Sea, Geo-Mar. Lett., 30, 187-206, https://doi.org/10.1007/s00367-010-0197-8, 2010b.

Pape, T., Bahr, A., Klapp, S. A., Abegg, F., and Bohrmann, G.: High-intensity gas seepage causes rafting of shallow gas hydrates in the southeastern Black Sea, Earth. Planet. Sc. Lett., 307, 3546, https://doi.org/10.1016/j.epsl.2011.04.030, 2011a. 
Pape, T., Feseker, T., Kasten, S., Fischer, D., and Bohrmann, G.: Distribution and abundance of gas hydrates in nearsurface deposits of the Håkon Mosby Mud Volcano, SW Barents Sea, Geochem. Geophy. Geosy., 12, Q09009, https://doi.org/10.1029/2011gc003575, 2011b.

Riedel, M., Collett, T. S., Malone, M. J., and Expedition 311 Scientists: Expedition 311 Summary. Proc. IODP, 311: Washington, DC (Integrated Ocean Drilling Program Management International, Inc.), https://doi.org/10.2204/iodp.proc.311.101.2006, 2006.

Shipboard Scientific Party: Explanatory notes, in: Proc. ODP, Init. Repts., 164, edited by: Paull, C. K., Matsumoto, R., Wallace, P. J., et al., College Station, TX (Ocean Drilling Program), 13-41, https://doi.org/10.2973/odp.proc.ir.164.102.1996, 1996.

Sultan, N., Bohrmann, G., Ruffine, L., Pape, T., Riboulot, V., Colliat, J.-L., De Prunelé, A., Dennielou, B., Garziglia, S., Himmler, T., Marsset, T., Peters, C. A., Rabiu, A., and Wei, J.: Pockmark formation and evolution in deepwater Nigeria: Rapid hydrate growth versus slow hydrate dissolution, J. Geophys. Res.-Sol. Ea., 119, 2679-2694, https://doi.org/10.1002/2013JB010546, 2014.
Suzuki, K., Schultheiss, P., Nakatsuka, Y., Ito, T., Egawa, K., Holland, M., and Yamamoto, K.: Physical properties and sedimentological features of hydrate-bearing samples recovered from the first gas hydrate production test site on Daini-Atsumi Knoll around eastern Nankai Trough, Mar. Pet. Geol., 66, 346-357, https://doi.org/10.1016/j.marpetgeo.2015.02.025, 2015.

Wei, J., Pape, T., Sultan, N., Colliat, J.-L., Himmler, T., Ruffine, L., de Prunelé, A., Dennielou, B., Garziglia, S., Marsset, T., Peters, C. A., Rabiu, A., and Bohrmann, G.: Gas hydrate distributions in sediments of pockmarks from the Nigerian margin - Results and interpretation from shallow drilling, Mar. Pet. Geol., 59, 359370, https://doi.org/10.1016/j.marpetgeo.2014.09.013, 2015.

Whiticar, M. J.: Carbon and hydrogen isotope systematics of bacterial formation and oxidation of methane, Chem. Geol., 161, 291314, https://doi.org/10.1016/S0009-2541(99)00092-3, 1999. 